\title{
Screening of Cognitive Dysfunction Using the Montreal Cognitive Assessment Test and Evaluation of Neurologic Complications in Turkish Adults With Sickle Cell Anemia
}

\author{
Türk Erişkin Orak Hücreli Anemi Hastalarında Montreal Bilişsel Değerlendirme \\ Ölçeği ile Kognitif Bozukluğunun Taranması ve Nörolojik Komplikasyonların \\ Değerlendirilmesi
}

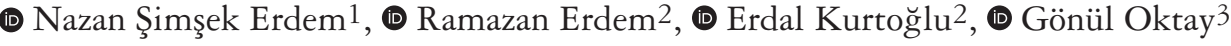 \\ ${ }^{1}$ Akdeniz University Hospital, Clinic of Neurology, Antalya, Turkey \\ 2Antalya Training and Research Hospital, Clinic of Hematology, Antalya, Turkey \\ 3 Hatay State Hospital, Clinic of Thalassemia Center, Hatay, Turkey
}

\begin{abstract}
Objective: To screen cognitive functions using the Montreal Cognitive Assessment (MoCA) test and to determine the most common central nervous system complications in adults with sickle cell anemia (SCA).

Materials and Methods: One hundred adult patients with SCA and 82 healthy controls participated in this study. Controls were matched for age, sex, and education level. We reviewed the demographic information and laboratory values of all patients. The patients were questioned about common CNS complications including headache, ischemic or hemorrhagic stroke, epilepsy, and cerebral venous sinus thrombosis. The MoCA test was used to assess neurocognitive function in all participants.

Results: Of the 100 patients with SCA, 38 patients had chronic or recurrent headaches, 10 had a history of depression, and four patients had a history of ischemic stroke. None of the patients had a history of epilepsy, hemorrhagic stroke or cerebral venous sinus thrombosis. The median MoCA score of the patients was significantly decreased compared with that of the control group ( $\mathrm{p}<0.001)$. MoCA scores below 21 points were observed in $50 \%$ of the patients. The MoCA scores were negatively correlated with age but positively correlated with education level $(r=-0.181 \mathrm{p}=0.015, \mathrm{r}=0.483, \mathrm{p}<0.001$ respectively). There was a significant correlation between a history of chronic or recurrent headaches and lower MoCA ( $\mathrm{p}=0.003)$.

Conclusion: Cognitive impairment was the most prevalent neurologic symptom in Turkish adult patients with SCA. The MoCA test may be a useful and easy screening test to evaluate and follow cognitive impairment. A history of first ischemic stroke during adulthood was observed in one patient. Two patients had severe neurologic sequela findings due to ischemic stroke.

Keywords: Neurocognitive dysfunction, adults with sickle cell anemia, Montreal Cognitive Assessment test, neurologic complications, Turkish population

$\ddot{\mathbf{O} z}$

Amaç: Orak hücre anemili (OHA) erişkin hastaların Montreal Bilişsel Değerlendirme (MoCA) testi ile bilişsel işlevlerini değerlendirmek ve bu hastalarda sık karşılaşılan merkezi sinir sistemi komplikasyonlarınını belirlemektir.

Gereç ve Yöntem: Çalışmaya 100 OHA tanılı erişkin hasta ve 82 sağlıklı kontrol grubu dahil edildi. Kontrol grubu ile hasta grup yaş, cinsiyet ve eğitim açısından eşleştirildi. Tüm hastaların demografik bilgileri ve laboratuvar değerleri kaydedildi. Hastalar kronik veya sık aralıklı baş ağrısı, iskemik veya hemorajik inme, epilepsi, serebral venöz sinüs trombozu gibi yaygın santral sinir sistemi komplikasyon öyküleri olup olmadı̆̆ açısından sorgulandı. Çalışmaya alınan tüm bireylerin bilişsel fonksiyonları MoCA testi ile değerlendirildi.

Bulgular: Yüz OHA'lı hastanın 38'inde kronik veya tekrarlayan baş ağrısı, 10’ununda depresyon öyküsü, 4’ünde iskemik inme öyküsü vardı. Hiçbir hastada epilepsi, hemorajik inme ve serebral venöz sinüs trombozu öyküsü yoktu. Hastaların medyan MoCA skorları kontrol grubuna göre anlamlı olarak düşüktü ( $<<0,001)$. Hastaların \%50'sinde 21 puanın altında MoCA skorları gözlendi. Hastaların MoCA total puanları yaş ile negatif, eğitim düzeyi ile pozitif korelasyon gösterdi ( $\mathrm{r}=-0,181 \mathrm{p}=0,015, \mathrm{r}=0,483 \mathrm{p}<0,001)$. Kronik veya tekrarlayan baş ağrısı öyküsü düşük MoCA skoru ile anlamlı derecede ilişkili idi ( $\mathrm{p}=0,003$ ).
\end{abstract}

Address for Correspondence/Yazışma Adresi: Nazan Şimşek Erdem MD, Akdeniz University Hospital, Clinic of Neurology, Antalya, Turkey Phone: +90 2422496142 E-mail: naazansimsek@hotmail.com ORCID: orcid.org/0000-0003-4612-1062

Received/Geliss Tarihi: 04.06.2020 Accepted/Kabul Tarihi: 16.03.2021

${ }^{\circ}$ Copyright 2021 by Turkish Neurological Society

Turkish Journal of Neurology published by Galenos Publishing House. 
Sonuç: OHA'lı Türk erişkin hastalarda en sık görülen nörolojik semptom bilişsel bozukluktu. MoCA testi, OHA'lı hastalarda bilişsel bozukluğu değerlendirmek ve takip etmek için yararlı ve kolay bir tarama testi olabilir. Erişkinlik döneminde iskemik inme bir hastada gözlendi. İki hastada iskemik inme nedeniyle ciddi nörolojik sekel bulguları gözlendi.

Anahtar Kelimeler: Bilişsel bozukluk, orak hücreli anemili erişkin, Monteral Bilişsel Değerlendirme testi, nörolojik komplikasyonlar, Türkiye popülasyonu

\section{Introduction}

Sickle cell disease (SCD) is an autosomal recessive hemoglobinopathy caused by a mutation of the beta-globin allele that decreases or destroys normal beta-globin production and leads to the production of sickle hemoglobin. Sickle hemoglobin becomes less resolvable than normal hemoglobin when deoxygenated. SCD occurs most commonly in the Middle East, sub-Saharan Africa, and India, and it has also become relatively prevalent in Western Europe and America after migration (1). Sickle cell anemia (SCA) is also frequently observed in Turkey, especially in the Cukurova district of southern Turkey (2).

Central nervous system (CNS) complications in SCD are linked to increased morbidity and mortality. In the literature, CNS complications including silent cerebral infarct, ischemic or hemorrhagic stroke, cerebral venous sinus thrombosis, epilepsy, posterior reversible encephalopathy syndrome, cerebral fat embolism, and neurocognitive deficits have been reported in patients with SCA $(3,4,5,6,7,8)$. Silent cerebral infarct (SCI) is the most frequent CNS complication in children with SCA, and possibly also in adults $(8,9)$. SCI is associated with neurocognitive deficits, especially in executive functions and academic difficulties in children with SCA $(10,11,12)$. Even in the absence of SCI, cognitive impairments such as low intelligence quotient (IQ) scores, impaired executive function, and learning difficulties are prevalent in children with SCA $(13,14,15,16,17,18)$. Additionally, neurocognitive impairment, which may worsen with age, and anemia have been reported in adult patients with SCA without neurologic symptoms (19). Although many significant studies have described neurocognitive impairment in children with SCA, few studies have evaluated cognitive functioning in adults with SCA $(20,21,22)$. To the best of our knowledge, there is no validated and standardized screening neurocognitive tool for adult patients with SCA. A previous study has shown that the Montreal Cognitive Assessment (MoCA) might be an efficient and reliable neurocognitive test for adult patients with SCA (22). The present study aimed to assess the frequency of the most common CNS complications and to screen cognitive dysfunctions using the MoCA test in Turkish adult patients with SCA in a random sample.

\section{Materials and Methods}

This retrospective cross-sectional study was allowed by the University of Health Sciences Turkey, Antalya Training and Research Hospital Ethics Committee (approval number: 201912/16). We enrolled 100 adult patients with homozygous sickle mutation from the University of Health Sciences Turkey, Antalya Training and Research Hospital and Hatay State Hospital Hemoglobinopathy Clinic centers in Turkey and 82 healthy control subjects (HCs) matched for sex, age, and education duration. Patients who had any history of recent acute severe painful crisis, illness, infection or drug use that could affect cognitive functions were excluded. When the neurocognitive test was conducted, records were made of demographic information and laboratory data. The patients were asked whether they had any common CNS complications associated with SCD, including ischemic or hemorrhagic stroke, epilepsy, and cerebral venous sinus thrombosis. The patients were asked if they had a chronic daily headache or frequent episodic headaches during the past year. A headache of almost any type that occurred generally for a minimum of 15 days each month for six months was defined as a chronic headache (23) and a headache that occurred more than once, but less than 15 episodes per month was defined as frequent episodic headache. Headache classification was assigned in line with the criteria proposed by the second edition of the International Classification of Headache Disorders. The patients were also asked about the number of episodes of severe acute painful crisis that necessitated treatment in an emergency department or hospitalization during the year before the evaluation. No records were made of the mild and self-limited acute painful episodes that were managed by patients at home.

MoCA was used for evaluating neurocognitive function in all participants. MoCA was designed to screen for mild cognitive impairment (MCI) by Nasreddine et al. (24). MoCA has high sensitivity and specificity to detect patients with MCI performing in the normal range on Mini-Mental State Examination (24). The assessment can be completed in approximately 10 to 15 minutes. MoCA has been adapted into Turkish by Selekler et al. (25) The Turkish version of MoCA (MoCA-TR) has been validated in Alzheimer's dementia and Parkinson's disease $(25,26,27)$. The MoCA-TR consists of seven cognitive domains: visuospatial abilities (drawing a clock, copying a cube, and an alternation task modified from the Trail-Making B task), naming (confrontation naming of 3 animals), attention (including the sum of attention, concentration, and working memory items), language (the sum of repetition of sentences and verbal fluency task scores), abstract thinking/executive functions (the 2-item verbal abstraction), short-term memory/recall, and orientation. The total MoCA score ranges from 0 to 30, with higher scores showing better cognition. In this study, cognitive impairment was identified by a score of $<21$ of MoCA-TR (25).

\section{Statistical Analysis}

Statistical analysis was performed using the Statistical Package for the Social Sciences 20.0 software package. Significance for all statistical analyses was assessed using a p value $<0.05$. Median (Q1Q3) was used to express variables and numbers and percentages were used to express categorical variables. The suitability of continuous variables to normal distribution was examined using the Shapiro-Wilk test. The differences between the percentages of categorical variables were analyzed using Pearson's chi-square test. Fisher's exact test was used when over $20 \%$ of the expected frequencies were less than 5. To determine the relationship 
between the two continuous variables, Spearman's correlation coefficient was used because the assumption of normality was not provided. The difference between the two independent groups was compared using the Mann-Whitney U test because the parametric test assumptions were not provided.

\section{Results}

One hundred adult patients with SCA with a median age of 30 (range: 18-56) years, comprising 60 females and 40 males, were included in the study. In the patient group, the median number of years of education was 10 (R: 5-16). Seventy-three patients did not complete more than 12 years of education and $50 \%$ of all patients completed eight or fewer years of education. Fifty-nine percent of the patients were neither working nor in school, ten patients were students, and 31 patients were working. During the previous year, the median number of acute severe painful crises was two (range: 0-24) in the patient group. Seventy-four patients had a history of hydroxyurea therapy and seven had both hydroxyurea therapy and routine erythrocyte exchange therapy.

Ninety-eight patients' neurologic examinations were normal and none of these had a history of epileptic seizure, hemorrhagic stroke, or cerebral venous sinus thrombosis. Thirty-eight patients $(38 \%)$ had chronic or frequent episodic headaches. All headache types were primary headaches including migraine or tension-type headache (TTH). Twenty-one of 38 patients had TTH. Ten patients had a history of depression and treatment with antidepressive drugs. A history of acute ischemic stroke was recorded in $4 \%$ of the patients. The first patient was a 25 -year-old female who at the age of 15 years had been diagnosed as having acute ischemic stroke with left-sided hemiparesis and severe headaches. Her symptoms resolved gradually after routine exchange therapy. The second patient was a 23-year-old male who had recurrent acute ischemic strokes consistent with brain magnetic resonance (MR) imaging during childhood and adulthood. The third was a 34-year-old male who developed left-side hemiplegia due to ischemic stroke at age 8 years and his symptoms did not improve after treatment. The first acute ischemic stroke during adulthood was observed in one patient, a 40-year-old male, who had a history of multiple silent cerebral infarcts and hypertension before the event of acute ischemic stroke. Table 1 shows the features of demographic and clinical and laboratory values of the patients with SCD.

No significant differences were seen among the patients and control groups for age, sex, and duration of education (all were $\mathrm{p}>0.05)$. The median MoCA-TR score was 20.5 (Q1: 17, Q3: 23) and $25(\mathrm{Q} 1: 23, \mathrm{Q} 3: 27)$ in the patient group and control group, respectively. The MoCA-TR scores were significantly decreased in the patient group compared with the control group $(\mathrm{p}<0.001)$. The patients had significantly poorer performance than the healthy control group in visuospatial and executive function, attention, language, abstraction, delayed recall, orientation domains (all $\mathrm{p}<0.05)$. No significant difference was recorded between the patients and healthy controls for the naming domain $(p=0.56)$. The scores in each domain and total MoCA-TR score of the patient group and the control group are summarized in Table 2. Fifty of the 100 patients had a score below 21 on the total MoCA-TR. No significant difference in the median MoCA-TR score was observed between men and women $(\mathrm{p}=0.95)$. The total MoCA-TR score was negatively correlated with age but positively associated with the number of years of education $(r=-0.181 \mathrm{p}=0.015, \mathrm{r}=0.483$ $\mathrm{p}<0.001$, respectively). Level of education was also closely associated with all domains of MoCA-TR (all $\mathrm{p}<0.05$ ).

The MoCA-TR scores were significantly decreased in unemployed adults compared with employed adults or students $(\mathrm{p}<0.001)$. The performances in visuospatial and executive function, attention, language, abstraction, delayed recall, and orientation domains were significantly lower in unemployed patients than in employed patients who or students (all $\mathrm{p}<0.05$ ). For the naming domain, there were no important differences between unemployed patients and employed or student patients $(\mathrm{p}=0.07)$.

No significant association was found between the previous year's number of acute severe painful crises and the MoCATR score $(r=0.1, p=0.29)$. The fetal hemoglobin levels $(\mathrm{Hb}-\mathrm{F})$, hemoglobin, hematocrit, reticulocyte count, liver enzymes, and ferritin were not correlated with MoCA-TR scores (all p>0.05). No significant difference in the median MoCA-TR score was observed between the patients and those who had not been treated with hydroxyurea $(\mathrm{p}=0.83)$. A history of chronic or frequent episodic headaches was associated with lower MoCA-TR $(\mathrm{p}=0.03)$. The patients with a history of chronic or frequent episodic headache

\section{Table 1. Demographic characteristics and laboratory values for the patients}

$$
\begin{aligned}
& \text { All patients } \mathbf{n}=100 \\
& 21(16,32.5) \\
& 2(0,24) \\
& 76 \\
& 9.2 \\
& 9.2(0.7,38.4) \\
& 458.5(10.9,2416) \\
& 4.95(0.45,13.3) \\
& 414(181,1489) \\
& 82(39,356) \\
& 24(5,299) \\
& 4 \\
& 38
\end{aligned}
$$

Hb-F: Fetal hemoglobin, BMI: Body mass index, LDH: Lactate dehydrogenase, ALP: Alkaline phosphatase, GGT: Gama glutamyl transferase, min: Minimum, max: Maximum 
Table 2. Demographic features, performances in each domain and total MoCA score of patients group and control group

\begin{tabular}{|c|c|c|c|}
\hline & Patients group median (Q1-Q3) & Control group median (Q1-Q3) & $\mathrm{p}$ \\
\hline Age (years) & $30(22-38.5)$ & $34(25-41)$ & 0.10 \\
\hline Duration of education (year) & $10(5-14)$ & $12(8-14)$ & 0.15 \\
\hline Visuospatial and executive function & $3(3-4)$ & $4.5(4-5)$ & $<0.001$ \\
\hline Naming & $3(2-3)$ & $3(2-3)$ & 0.56 \\
\hline Language & $1(1-2)$ & $2(2-3)$ & $<0.001$ \\
\hline Delayed recall & $2(0.5-3)$ & $3(2-4)$ & $<0.001$ \\
\hline Orientation & $6(5-6)$ & $6(6-6)$ & 0.001 \\
\hline Total MoCA score & $20.5(17-23)$ & $25(23-27)$ & $<0.001$ \\
\hline
\end{tabular}

had significantly lower performance than those without chronic or frequent episodic headache in the attention domain $(\mathrm{p}<0.001)$. No significant difference was observed between patients with and without a chronic or frequent episodic headache for visuospatial and executive function, language, naming, abstraction, delayed recall, and orientation domains (all p $>0.05$ ).

\section{Discussion}

Neurocognitive function in adults with SCA was evaluated in this study using the MoCA test and compared with a healthy community control group. Previous studies reported that MoCA could be an effective cognitive screening tool for neurologic diseases such as Parkinson's disease (28,29), Huntington's disease (30), vascular cognitive impairment (31), brain metastasis (32), sleep behavior disorder (33), multiple sclerosis (34), and other systemic disorders such as systemic lupus erythematosus (35), heart failure (36), and type 2 diabetes mellitus (37). Additionally, in the Turkish population, MoCA-TR has been reported as a brief, practical, and useful screening assessment method to identify cognitive impairment in neurologic disorders such as Alzheimer's disease and Parkinson's disease $(26,27)$, and other systemic disorders such as psoriasis (38). To the best of our knowledge, this study is the first to evaluate cognitive impairment in Turkish adults with SCA using the MoCA-TR. Our key finding was that half of the patients had cognitive impairment based on MoCA-TR. We also showed that adults with SCA had a lower cognitive performance on total MoCA-TR and visuospatial and executive function, attention, language, abstraction, delayed recall, and orientation domains than the healthy control group, which was matched for sex, age, and education duration. Vichinsky et al. (19) evaluated cognitive functions in adult patients with SCA without neurologic symptoms using very comprehensive neuropsychological tests and found that adults with SCA had lower performance on memory, language, learning, attention, and overall executive functioning than healthy control subjects, as in the present study. We conclude that MoCA-TR may identify important neurocognitive deficits, as found in previous studies in adults with SCA, as indicated in Cichowitz et al. (22).

Previous studies reported that stroke and/or SCIs (18), chronic brain hypoxia (15), older age (19), anemia (16,19), systemic inflammation (39), and social environment (40) were associated with neurocognitive dysfunction in patients with SCD. In our study, we showed that cognitive impairment deteriorated with age in adults with SCA, as in previous studies $(14,19,41)$. In our study, cognitive performances were not correlated with hemoglobin, hematocrit, level of $\mathrm{Hb}-\mathrm{F}$, reticulocyte count, liver enzymes or ferritin, as indicated by Cichowitz et al. (22). Mackin et al. (20) stated that reduced volume of the basal ganglia and thalamus was linked to lower cognitive measures in 120 adult patients with SCA. In the present study, we found that a history of chronic or frequent episodic headaches was associated with poorer cognitive performance, especially attention. We think that in adult patients with SCA, frequent episodic or chronic headaches accompanied by cognitive impairment may represent serious cranial involvement of SCD. Thus, neuropsychological and neuroimaging tests may be required in patients with SCA with recurrent or chronic headaches. Our study found no correlation between the number of acute severe painful crises in the previous year and cognitive deficit. We found that cognitive performance was positively correlated with education level, as indicated in previous studies $(19,20,22)$. We also observed that cognitive impairment was higher in unemployed adults with SCA, as suggested in a previous study (42). Special educational programs and neurocognitive rehabilitation programs can help patients with SCA to increase education levels and enter the workplace.

The prevalence of neurologic complications in SCD may be variable across countries due to national health coverage systems, primary healthcare facilities, public awareness of the disease, and adequate access to screening, diagnostic procedures, and preventive and therapeutic interventions. In the literature, several studies investigated the neurologic complications of SCD in the African population $(3,43,44)$. One study found that neurologic abnormalities occurred in $76 \%$ of Nigerian Africans with SCA (44). To the best of our knowledge, in the literature, there are no data about the neurologic complications of SCD in the Turkish population. The present study investigated the frequency of major common CNS complications of SCD in the Turkish adult population.

According to our findings, cognitive impairment was the most common neurologic symptom in our cohort. Chronic or frequent episodic headaches (38\%) were the second most common neurologic symptoms. As far as we are aware, there are limited data 
on the prevalence of recurrent or chronic headaches in adult patients with SCA. Previous studies estimated the prevalence of recurrent headaches in children and adolescents with SCD as 24.0-43.9\% and $24.0-43.9 \%$, respectively $(45,46)$. The largest retrospective cross-sectional study stated that recurrent headache $(36.1 \%)$ and migraine $(15.1 \%)$ were both frequently observed in children with SCA (46). The pathogenesis of headache in SCD remains obscure, but factors such as low hemoglobin level, high pain rate, stress, or blood flow abnormalities have been demonstrated as possible mechanisms $(46,47)$.

In this study, a history of ischemic acute stroke was identified in four patients with SCA. One history of ischemic stroke during adulthood, one history of recurrent ischemic stroke that developed during childhood and adulthood, and two histories of ischemic stroke during childhood were observed in our study. A previous study stated that in SCD, ischemic strokes were most frequently seen in children aged between 2 and 5 years and people over 30 years of age and stroke incidence varied depending on the sickle cell genotype (48). Strouse et al. (49) showed that patients with SCD had three times as many strokes as African-Americans of a similar age ( 35 to 64 years) and SCD was as important a risk factor for stroke in older adults as it was in young adults. Vasculopathy of the distal internal carotid arteries, middle cerebral arteries and/ or anterior cerebral arteries can cause ischemic stroke in SCD. Anemia, abnormal repeated sickling causing endothelial damage, chronic inflammation associated with hemolysis, leukocytosis, and hypoxemia contribute to this vasculopathy. Also, vasoconstriction, the dysregulation of the fibrinolytic and hemostatic system, activation of platelets, cytokine release, repeated cycles of sickling, and unsickling may lead to a systemic prothrombotic state in SCD (5). Gueguen et al. (50) showed that most hemorrhagic strokes occurred in adults and carried a higher risk of death than ischemic strokes in SCD. It has been reported that low hemoglobin levels, leukocytosis, a history of hypertension, recent transfusion, and corticosteroid treatment may be risk factors for intracranial hemorrhage in patients with SCD $(48,51)$.

In the literature, cases of cerebral venous sinus thrombosis in SCD are relatively uncommon $(52,53)$. Ali et al. (6) demonstrated that the frequency of epilepsy in patients with SCA was $6.8 \%$ and was 2-3 times more prevalent than in non-sickle populations. In the present study, none of the patients had a history of epilepsy, cerebral venous sinus thrombosis, or hemorrhagic stroke during their lifetime.

In this study, a history of depression was recorded in $10 \%$ of patients. However, we could not evaluate the presence and severity of depression in our patients with psychiatric tests. In a study of adults with SCD, it was reported that the prevalence of depression was $\sim 5$ times higher than that of the general population (54). Wallen et al. (55) also reported that $20 \%$ of patients with SCD were depressed according to the Beck Depression Inventory.

\section{Study Limitations}

There were several limitations to our retrospective crosssectional study. Brain imaging tests and electroencephalography (EEG) could not be performed on the patients and this was an important limiting factor. Prospective studies should evaluate the frequency of neurologic complications of SCD in the Turkish population using diagnostic tools such as neuroimaging, transcranial Doppler, EEG, and neuropsychological evaluation.
Further studies with large numbers of patients are needed to evaluate the neurocognitive dysfunction and risk factors for cognitive impairment in SCD adults.

To the best of our knowledge, this study is the first to investigate the frequency of major common CNS complications of SCD and neurocognitive function in the Turkish population with SCD, despite the limitations of this study.

\section{Conclusion}

The early detection of cognitive impairment may ensure that patients have access to neurocognitive and vocational rehabilitation programs. Thus, physicians should screen and follow-up cognitive functions in adults with SCD. Our findings suggest that the MoCA test may be an easy-to-administer screening and follow-up test for cognitive impairment until a validated and standardized screening tool exists for adult patients with SCD.

\section{Ethics}

Ethics Committee Approval: This retrospective crosssectional study was allowed by the University of Health Sciences Turkey, Antalya Training and Research Hospital Ethics Committee (approval number: 2019-12/16).

Informed Consent: All patients provided written informed consent according to the Declaration of Helsinki.

Peer-review: Externally peer-reviewed.

\section{Authorship Contributions}

Concept: N.Ş.E., R.E., G.O., E.K., Design: N.Ş.E., R.E., G.O., E.K., Data Collection or Processing: N.Ş.E., R.E., G.O., E.K., Analysis or Interpretation: N.Ş.E., R.E., G.O., E.K., Literature Search: N.Ş.E., R.E., G.O., E.K., Writing: N.Ş.E., R.E., G.O., E.K.

Conflict of Interest: No conflict of interest was declared by the authors.

Financial Disclosure: The authors declared that this study received no financial support.

\section{References}

1. Piel FB, Patil AP, Howes RE, et al. Global epidemiology of sickle haemoglobin in neonates: a contemporary geostatistical model-based map and population estimates. Lancet 2013;381:142-151.

2. Curuk MA, Zeren F, Genc A, et al. Prenatal diagnosis of sickle cell anemia and beta-thalassemia in southern Turkey. Hemoglobin 2008;32:525-530.

3. Mengnjo MK, Kamtchum-Tatuene J, Nicastro N, Noubiap JJ. Neurological complications of sickle cell disease in Africa: protocol for a systematic review. BMJ Open 2016;6:e012981.

4. Alkan O, Kizilkilic E, Kizilkilic O, et al. Cranial involvement in sickle cell disease. Eur J Radiol 2010;76:151-156.

5. Farooq S, Testai FD. Neurologic complications of sickle cell disease. Curr Neurol Neurosci Rep 2019;19:17.

6. Ali SB, Reid M, Fraser R, MooSang M, Ali A. Seizures in the Jamaica cohort study of sickle cell disease. Br J Haematol 2010;151:265-272.

7. Solh Z, Taccone MS, Marin S, Athale U, Breakey VR. Neurological PRESentations in sickle cell patients are not always stroke: a review of posterior reversible encephalopathy syndrome in sickle cell disease. Pediatr Blood Cancer 2016;63:983-989.

8. DeBaun MR, Kirkham FJ. Central nervous system complications and management in sickle cell disease. Blood 2016;127:829-838.

9. DeBaun MR, Armstrong FD, McKinstry RC, et al. Silent cerebral infarcts: a review on a prevalent and progressive cause of neurologic injury in sickle cell anemia. Blood 2012;119:4587-4896.

10. DeBaun MR, Schatz J, Siegel MJ, et al. Cognitive screening examinations for silent cerebral infarcts in sickle cell disease. Neurology 1998;50:1678-1682. 
11. Brown RT, Davis PC, Lambert R, et al. Neurocognitive functioning and magnetic resonance imaging in children with sickle cell disease. J Pediatr Psychol 2000;25:503-513.

12. Schatz J, Brown RT, Pascual JM, Hsu L, DeBaun MR. Poor school and cognitive functioning with silent cerebral infarcts and sickle cell disease. Neurology 2001;56:1109-1111.

13. Steen RG, Miles MA, Helton KJ, et al. Cognitive impairment in children with hemoglobin SS sickle cell disease: relationship to MR imaging findings and hematocrit. AJNR Am J Neuroradiol 2003;24:382-389.

14. Steen RG, Fineberg-Buchner C, Hankins G, et al. Cognitive deficits in children with sickle cell disease. J Child Neurol 2005;20:102-107.

15. Hogan AM, Pit-ten Cate IM, Vargha-Khadem F, Prengler M, Kirkham FJ Physiological correlates of intellectual function in children with sickle cell disease: hypoxaemia, hyperaemia and brain infarction. Dev Sci 2006;9:379387.

16. Bernaudin F, Verlhac S, Freard F, et al. Multicenter prospective study of children with sickle cell disease: radiographic and psychometric correlation. J Child Neurol 2000;15:333-343.

17. Kral MC, Brown RT, Connelly M, et al. Radiographic predictors of neurocognitive functioning in pediatric Sickle Cell disease. J Child Neurol 2006;21:37-44.

18. Schatz J, White DA, Moinuddin A, Armstrong M, DeBaun MR. Lesion burden and cognitive morbidity in children with sickle cell disease. J Child Neurol 2002;17:891-895.

19. Vichinsky EP, Neumayr LD, Gold JI, et al. Neuropsychological dysfunction and neuroimaging abnormalities in neurologically intact adults with sickle cell anemia. JAMA 2010;303:1823-1831.

20. Mackin RS, Insel P, Truran D, et al. Neuroimaging abnormalities in adults with sickle cell anemia: associations with cognition. Neurology 2014;82:835-841.

21. Stotesbury H, Kirkham FJ, Kolbel M, et al. White matter integrity and processing speed in sickle cell anemia. Neurology 2018;90:e2042-e2050.

22. Cichowitz C, Carroll PC, Strouse JJ, Haywood C Jr, Lanzkron S. Utility of the Montreal Cognitive Assessment as a screening test for neurocognitive dysfunction in adults with sickle cell disease. South Med J 2016;109:560565 .

23. Silberstein SD, Lipton RB, Sliwinski M. Classification of daily and near-daily headaches: field trial of revised IHS criteria. Neurology 1996;47:871-875.

24. Nasreddine ZS, Phillips NA, Bédirian V, et al. The Montreal Cognitive Assessment, MoCA: a brief screening tool for mild cognitive impairment. J Am Geriatr Soc 2005;53:695-699.

25. Selekler K, Cangöz B, Sait U. Power of discrimination of Montreal Cognitive Assessment (MOCA) Scale in Turkish patients with mild cognitive impairement and Alzheimer's Disease. Turk J Geriatr 2010;13:168.

26. Ozdilek B, Kenangil G. Validation of the Turkish Version of the Montreal Cognitive Assessment Scale (MoCA-TR) in patients with Parkinson's disease. Clin Neuropsychol 2014;28:333-343.

27. Kaya Y, Aki OE, Can UA, et al. Validation of montreal cognitive assessment and discriminant power of montreal cognitive assessment subtests in patients with mild cognitive impairment and alzheimer dementia in Turkish population. J Geriatr Psychiatry Neurol 2014;27:103-109.

28. Dalrymple-Alford JC, MacAskill MR, Nakas CT, et al. The MoCA: wellsuited screen for cognitive impairment in Parkinson disease. Neurology 2010;75:1717-1725

29. Kasten M, Bruggemann N, Schmidt A, Klein C. Validity of the moca and mmse in the detection of mci and dementia in parkinson disease. Neurology 2010;75:478-479.

30. Videnovic A, Bernard B, Fan W, et al. The Montreal Cognitive Assessment as a screening tool for cognitive dysfunction in Huntington's disease. Mov Disord 2010;25:401-404.

31. Wong A, Xiong YY, Kwan PW, et al. The validity, reliability and clinical utility of the Hong Kong Montreal Cognitive Assessment (HK-MoCA) in patients with cerebral small vessel disease. Dement Geriatr Cogn Disord 2009;28:81-87.

32. Olson RA, Chhanabhai T, McKenzie M. Feasibility study of the Montreal Cognitive Assessment (MoCA) in patients with brain metastases. Support Care Cancer 2008;16:1273-1278.

33. Gagnon JF, Postuma RB, Joncas S, Desjardins C, Latreille V. The Montreal Cognitive Assessment: a screening tool for mild cognitive impairment in REM sleep behavior disorder. Mov Disord 2010;25:936-940.
34. Charest K, Tremblay A, Langlois R, Roger É, Duquette P, Rouleau I. Detecting subtle cognitive impairment in multiple sclerosis with the montreal cognitive assessment. Can J Neurol Sci 2020;47:620-626.

35. Paez-Venegas N, Jordan-Estrada B, Chavarria-Avila E, et al. The montreal cognitive assessment test: a useful tool in screening of cognitive impairment in patients with systemic lupus erythematosus. J Clin Rheumatol 2019;25:325-328.

36. Cameron J, Worrall-Carter L, Page K, et al. Does cognitive impairment predict poor self-care in patients with heart failure? Eur J Heart Fail 2010;12:508-515.

37. Alagiakrishnan K, Zhao N, Mereu L, Senior P, Senthilselvan A. Montreal cognitive assessment is superior to standardized mini-mental status exam in detecting mild cognitive impairment in the middle-aged and elderly patients with type 2 diabetes mellitus. Biomed Res Int 2013;2013:186106.

38. Colgecen E, Celikbilek A, Keskin DT. Cognitive impairment in patients with psoriasis: a cross-sectional study using the montreal cognitive assessment. Am J Clin Dermatol 2016;17:413-419.

39. Andreotti C, King AA, Macy E, Compas BE, DeBaun MR. The association of cytokine levels with cognitive function in children with sickle cell disease and normal mri studies of the brain. J Child Neurol 2015;30:1349-1353.

40. King AA, Strouse JJ, Rodeghier MJ, et al. Parent education and biologic factors influence on cognition in sickle cell anemia. Am J Hematol 2014;89:162-167.

41. Ruffieux N, Njamnshi AK, Wonkam A, et al. Association between biological markers of sickle cell disease and cognitive functioning amongst Cameroonian children. Child Neuropsychol 2013;19:143-160.

42. Sanger M, Jordan L, Pruthi S, et al. Cognitive deficits are associated with unemployment in adults with sickle cell anemia. J Clin Exp Neuropsychol 2016;38:661-671.

43. Noubiap JJ, Mengnjo MK, Nicastro N, Kamtchum-Tatuene J. Neurologic complications of sickle cell disease in Africa: A systematic review and metaanalysis. Neurology 2017;89:1516-1524.

44. Kehinde MO, Temiye EO, Danesi MA. Neurological complications of sickle cell anemia in Nigerian Africans--a case-control study. J Natl Med Assoc 2008;100:394-399

45. Niebanck AE, Pollock AN, Smith-Whitley K, et al. Headache in children with sickle cell disease: prevalence and associated factors. J Pediatr 2007;151:67-72.e1.

46. Dowling MM, Noetzel MJ, Rodeghier MJ, et al. Headache and migraine in children with sickle cell disease are associated with lower hemoglobin and higher pain event rates but not silent cerebral infarction. J Pediatr 2014;164:1175-1180.e1.

47. Silva GS, Vicari P, Figueiredo MS, et al. Migraine-mimicking headache and sickle cell disease: a transcranial Doppler study. Cephalalgia 2006;26:678683.

48. Ohene-Frempong K, Weiner SJ, Sleeper LA, et al. Cerebrovascular accidents in sickle cell disease: rates and risk factors. Blood 1998;91:288-294.

49. Strouse JJ, Jordan LC, Lanzkron S, Casella JF. The excess burden of stroke in hospitalized adults with sickle cell disease. Am J Hematol 2009;84:548552.

50. Gueguen A, Mahevas M, Nzouakou R, et al. Sickle-cell disease stroke throughout life: a retrospective study in an adult referral center. Am J Hematol 2014;89:267-272.

51. Strouse JJ, Hulbert ML, DeBaun MR, Jordan LC, Casella JF. Primary hemorrhagic stroke in children with sickle cell disease is associated with recent transfusion and use of corticosteroids. Pediatrics 2006;118:19161924.

52. Oguz M, Aksungur EH, Soyupak SK, Yildirim AU. Vein of Galen and sinus thrombosis with bilateral thalamic infarcts in sickle cell anaemia: CT followup and angiographic demonstration. Neuroradiology 1994;36:155-156.

53. Ciurea SO, Thulborn KR, Gowhari M. Dural venous sinus thrombosis in a patient with sickle cell disease: case report and literature review. Am J Hematol 2006;81:290-293.

54. Adam SS, Flahiff CM, Kamble S, et al. Depression, quality of life, and medical resource utilization in sickle cell disease. Blood Adv 2017;1:19831992

55. Wallen GR, Minniti CP, Krumlauf M, et al. Sleep disturbance, depression and pain in adults with sickle cell disease. BMC Psychiatry 2014;14:207. 